International Journal for Crime, Justice and Social Democracy

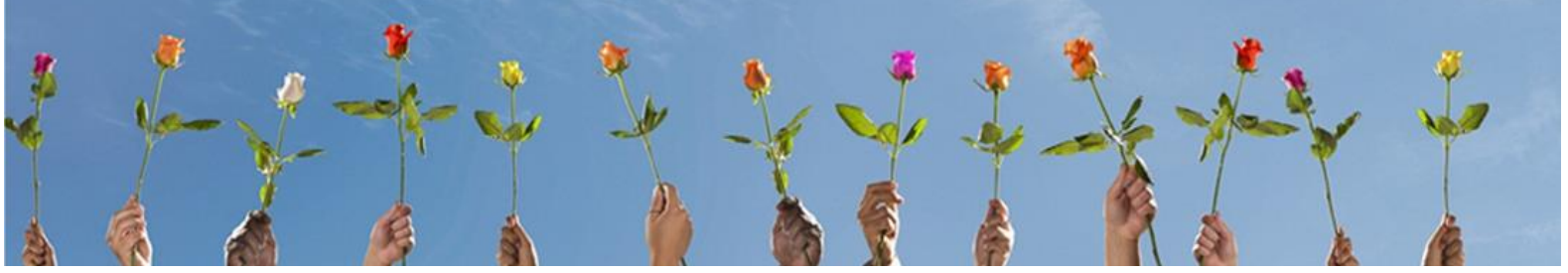

\title{
Gender-Based Violence, Law Reform, and the Criminalization of Survivors of Violence
}

\author{
Leigh Goodmark \\ University of Maryland Francis King Carey School of Law, United States
}

\begin{abstract}
Criminalization is the primary societal response to intimate partner violence in the US. This reliance on criminal legal system interventions ignores several unintended consequences. One of the serious unintended consequences of criminalization - perhaps the most serious unintended consequence - has been the increased rates of arrest, prosecution, conviction, and incarceration of those whom criminalization was meant to protect: victims of intimate partner violence. Criminalized survivors follow a variety of pathways into the carceral system, which fails to recognize their status as victims of violence and punishes them for failure to conform to victim stereotypes as well as for their acts.
\end{abstract}

\section{Keywords}

Intimate partner violence; criminal legal system; criminalized survivors; abolition; abolition feminism.

Please cite this article as:

Goodmark L (2021) Gender-based violence, law reform, and the criminalization of survivors of violence. International Journal for Crime, Justice and Social Democracy 10(4): 13-25. https://doi.org/10.5204/ijcjsd.1994

Except where otherwise noted, content in this journal is licensed under a Creative Commons Attribution 4.0 International Licence. As an open access journal, articles are free to use with proper attribution. ISSN: 2202-8005 


\section{Introduction}

For the last 35 years, the criminal legal system has been the primary societal response to intimate partner violence in the US. Anti-violence advocates tout legislative victories, increased intervention and enforcement by police and prosecutors, and harsher penalties as proof of society's dedication to ensuring that those who commit intimate partner violence will be held accountable. However, one of the serious unintended consequences - perhaps the most serious unintended consequence - of those efforts has been the increased rates of arrest, prosecution, conviction, and incarceration of those whom these changes were meant to protect: victims of violence. So many victims of violence have been caught up in the criminal legal system in recent years that an entire movement in the US - known by the hashtag \#SurvivedandPunished - has emerged to protest their revictimization by the criminal legal system. This article will review the history of criminalization of intimate partner violence in the US, then turn to the particular impact of criminalization on survivors of violence arrested and prosecuted for incidents related to their own victimization. The article will conclude by arguing that survivors will always be harmed by a system that relies disproportionately on criminalization to address intimate partner violence and advocate for an abolition feminist approach.

\section{Criminalizing Intimate Partner Violence in the US}

Although the enforcement of laws meant to curb gender-based violence in the US has waxed and waned over time, by the 1970s, police and prosecutors routinely took a non-interventionist approach to intimate partner violence. The police training manuals of the time told officers not to intervene in what they called "domestic problems." Instead, officers were instructed to take the men (at that time, it was always men, and always husbands) for a walk around the block to de-escalate the situation (Schechter 1982). Believing that the lack of police response endangered victims of violence, some activists in the feminist anti-violence movement, which grew out of the women's liberation movement of the 1960s and 70s, began to demand that police treat intimate partner violence like any other crime. Activists argued that police were abusing their discretion by failing to make arrests in cases involving intimate partner violence. In 1976, lawyers in New York and Oakland, California, made that same argument in court, filing class action lawsuits alleging that police failure to make arrests violated the rights of survivors of violence. Those cas es resulted in settlements requiring police to adopt pro-arrest policies in both cities (Goodmark 2021).

The demand for more stringent arrest policies was bolstered by a study released in 1984 suggesting that arrest could deter recidivist intimate partner violence. The Minneapolis Domestic Violence Experiment found that arrest was more effective in preventing future violence than either of the other standard police responses of the time: removing the person who used violence from the home for a period or giving advice to both parties. Based on this research, the study's authors, Lawrence Sherman and Richard Berk, advocated for a presumption of arrest (pro-arrest policy) rather than a requirement of arrest (mandatory arrest policy) in cases involving intimate partner violence and cautioned that the study should be replicated before states enacted such policies (Sherman and Berk 1984). However, jurisdictions throughout the US, eager to avoid multimillion-dollar judgments - like the one awarded to Tracy Thurman in Thurman v. City of Torrington, Connecticut (1984) due to habitual police inaction in the face of her husband's repeated violence - seized upon mandatory and preferred arrest policies as their preferred solution. By 1989, 89 percent of police departments in the US had adopted mandatory or preferred arrest policies (Gruber 2019).

While arrest rates rose due to mandatory arrest policies, prosecution rates initially stayed flat. When pushed on their failure to prosecute, prosecutors explained that victim reluctance to testify stymied their efforts; without victims' testimony, they claimed, they could not meet their burdens of proof. Two innovations resulted from these claims. Prosecutors adopted evidence-based prosecution policies, relying on evidence other than victim testimony (including police records, hospital records, photographs, and other witness testimony) to prosecute any case that could be successfully brought without the victim's appearance. Prosecutors also adopted no-drop prosecution policies, pledging to prosecute any case that 
could be pursued, regardless of the victim's preference. In soft no-drop prosecution jurisdictions, prosecutors created incentives for victims to testify, including access to support services and crime victim compensation funds. In hard no-drop prosecution jurisdictions, prosecutors used any legal tactic available to secure victim testimony, including subpoenaing unwilling victims, asking courts to issue arrest warrants for those victims who did not appear pursuant to a valid subpoena, and, in extreme cases, requesting that victims be incarcerated until they gave testimony. Approximately two-thirds of prosecutors' offices had adopted some form of no-drop prosecution policy by 1996 (Goodmark 2018).

The passage of the Violence Against Women Act (VAWA) in 1994 further bolstered criminalization. Although VAWA created and supports various programs addressing intimate partner and other forms of gender-based violence, it is primarily a funding bill - and it primarily funds the criminal legal system. One study found that, as of 2013, 85 percent of VAWA funding was dedicated to the criminal legal system (Messing et al. 2015), although that number has been disputed by advocates. In 2019, VAWA's two largest programs - the Services * Training * Officers * Prosecutors (STOP) Grant Program and the Improving Criminal Justice Responses to Sexual Assault, Domestic Violence, Dating Violence, and Stalking Grant Program - channeled US $\$ 268$ million to courts, police, prosecutors, and community-based agencies supporting law enforcement's mission. Money also flows to the criminal legal system through other VAWA grant programs (Sacco 2019). VAWA has promoted criminalization in other ways: by defining intimate partner violence using the language of the criminal law, creating new crimes of intimate partner violence, and predicating eligibility for grant funding on the adoption of mandatory or preferred arrest policy (Goodmark 2020).

Criminalization's effectiveness in decreasing intimate partner violence is questionable. VAWA's champions, including President Joseph R. Biden, Jr., claim that VAWA is responsible for a substantial decline in rates of intimate partner violence since its passage. However, all rates of violent crime in the US have fallen significantly since 1994. Between 1994 and 2012, rates of intimate partner violence fell less than the drop in the overall crime rate: 63 percent versus 67 percent (Truman and Morgan, 2014). Moreover, the number of incidents of intimate partner violence in the US rose substantially between 2016 and 2018 before dipping in 2019 (Morgan and Truman 2020). Intimate partner violence increased by 8 percent in 2020, in the face of a global pandemic and despite continued financial support for criminalization (Piquero et al. 2021). There is no clear evidentiary support for the proposition that criminalization, via arrest, prosecution, conviction, or incarceration, deters intimate partner violence (Goodmark 2018).

Even if criminalization was deterring intimate partner violence, it would be appropriate to ask whether the costs of that deterrence are too high. Criminalization of intimate partner violence should be viewed in the broader context of hyper-criminalization and mass incarceration in the US. As of 2020, almost 2.3 million people in the US were incarcerated; the US incarcerates more people than any country in the world (Sawyer and Wagner 2020). The impact of mass incarceration falls disproportionately on people of color, particularly Black people (Bronson and Carson 2019). Although no national data on the number of people incarcerated for intimate partner violence in the US exists, approximately 21 percent of violent crime in the US involves intimate partner violence (Truman and Morgan 2014), which provides a basis to extrapolate what those numbers might be.

\section{Criminalizing Survivors in the US}

Criminalizing intimate partner violence has had significant unintended consequences for victims of violence. However, punitive intervention by the criminal legal system as a response to victims' efforts to defend themselves or otherwise respond to intimate partner violence is not a new phenomenon - these stories go back hundreds of years. Historically, law professor Carolyn Ramsey has argued, judges and juries in the US were not uniformly unsympathetic to women's self-defense arguments (Ramsey 2011). By the 1970s, however, women were much more likely to plead guilty in such cases than to be acquitted (Ramsey forthcoming) - an indication that judges and juries had grown more hostile to such claims. 
By the 1980s, women's self-defense claims had become the subjects of high-profile trials - like the trial of Judy Norman, who shot her sleeping husband after years of horrific abuse. Judy Norman was charged with first-degree murder. At trial, the defense introduced extensive evidence of J. T. Norman's history of abusing Judy Norman. However, Judge John Gardner refused to give the jury an instruction on self-defense (Mahoney 2019). The jury declined to convict Judy Norman of murder but found her guilty of manslaughter. After the verdict, District Attorney Alan Leonard said, "I was concerned from day one about the example that would be set in this case ... If Mrs. Norman didn't get some active sentence, that would in effect give the court's approval to an intentional homicide" (United Press International 1987). The national media shared Leonard's concern, with outlets such as CBS's 60 Minutes reporting on how women were "getting away with murder" (Schechter 1982: 173). Judy Norman was sentenced to six years of incarceration, a sentence upheld by the North Carolina Supreme Court (Mahoney 2019). Norman's case was not unusual for the time. In fact, as gender and sexuality studies professor Emily Thuma noted, "most abuse survivors who killed in self-defense in the 1970s and early 1980s were convicted rather than acquitted, and incarcerated rather than sentenced to probation" (Thuma 2019: 107). Acquitted women were newsworthy because "they were the exception and not the rule" (Jones 1996: 292).

Some women did ultimately escape criminal punishment. Edna Louise Pipkins killed her boyfriend after two years of abuse and 23 calls to the police. When the charges against her were dropped in 1980, the Women Free Women in Prison Project commented that:

... in legal terms it is said that Edna Louise Pipkin [sic] won her case. It would be more accurate to say that she escaped the usual punishment of imprisonment faced by most poor women of color who fight back against their batterers. (Thuma 2019: 106)

More recently, the media reported the story of Letoya Ramseure, who killed her boyfriend after he threatened to kill her, pushed his way into her home in defiance of a protective order, and assaulted both Ramseure and her mother. Ramseure was initially charged with third-degree murder but ultimately tried for manslaughter. Although the district attorney argued that Ramseure was jealous rather than afraid and lacked visible injuries after the incident, a jury found Ramseure not guilty (Melamed 2019). However, that freedom comes at a cost - time spent in jail pending trial, money paid toward bail, separation from children and loved ones, the publicity surrounding self-defense cases, and the trauma of the criminal legal process.

Several factors may be responsible for the growing numbers of survivors prosecuted for crimes related to their own victimization. First, law professor Carolyn Ramsey has suggested that women's increasing economic power and the liberalization of divorce laws created expectations that women would simply end violent relationships (Ramsey 2013). The self-defense claims of women who failed to take advantage of this perceived newfound freedom to leave their violent partners were seen as not credible, prompting prosecutors to pursue those cases. Similarly, the availability of both criminal and civil laws and policies specifically designed to protect survivors of intimate partner violence has created expectations that survivors will take advantage of those provisions by seeking protective orders, supporting the arrests of their partners, participating in prosecution, and asking for incarceration. The failure of some victims to use the legal system has prompted questions about why victims refuse to cooperate with police and prosecutors or leave their abusive partners rather than acting in self-defense or affirmatively fighting back. Finally, advocates learned that they could not control the carceral system they unleashed. Criminalization was initially intended to hold perpetrators (men) accountable for their violence against victims (women). Anti-violence advocates thought they would be able to control how law enforcement responded to intimate partner violence, a dance that social work professor Mimi Kim described as "the carceral creep" (Kim 2020: 256). However, advocates could not prevent police and prosecutors from enforcing the law as they saw fit, leaving criminalized survivors vulnerable to punitive interventions.

How law enforcement perceived survivors of violence also contributed to their criminalization. The gendered rhetoric of criminalization created unrealistic stereotypes of people subjected to abuse. 
Blameless victims (usually women) were pitted against monstrous perpetrators (usually men). Blamelessness guaranteed that victims would be treated sympathetically: "the 'true' or 'worthy' victim loses some of her halo if her presentation falters" (Dunn 2002: 83). Victims of violence were expected to present as weak, meek, and passive (Goodmark 2012). Victims of violence do not always - or even often - conform to these stereotypes, however. The legal system is confounded by women who fail to fit victim stereotypes - who use force to defend themselves or who are angry, for example. Such women face a hostile legal system disinclined to believe their claims. One example: a woman who was being stalked by an ex-boyfriend against whom she had a protective order repeatedly called police, to no avail. She finally fought back against her stalker, who was later tried for violating the protective order. A judge noted her requests for help but said, "at the same time, she seems to put up a fairly tough exterior here." The woman's "tough exterior" coupled with her willingness to confront her stalker likely led to his acquittal - despite his admission that he had repeatedly violated the order (Dunn 2002: 95-97).

"Women who are abrasive and argumentative, who are aggressive towards their abusers for any reason (including self-defense), or who otherwise fail to conform to traditional female gender roles" are "bad" victims (Rajan and McCloskey 2009: 36). Sex workers are bad victims (Ritchie 2017), as are lesbians (Machado 2019) and trans people (Goodmark 2013). So are women of color, particularly Black women (Richie 2012; Ritchie 2017). As anti-trafficking activist and consultant Holly Joshi observed, Black women have never been seen as survivors or good victims, but rather as tools that the criminal legal system can use to punish Black men (Personal interview 2020) Bad victims are more likely to be arrested (Rajan and McCloskey 2009). Once victimized women become criminal defendants, the opportunity to be seen as a "good victim" all but vanishes; at best, they might be labeled "victim-offenders" (Musto 2016). As sociologist Elizabeth Comack wrote, "crime categories are premised on a binary opposition or dualism between 'the criminal' and 'the law abiding.' Those who are processed through the system and end up in prison are relegated to the criminal side of the equation. The net effect is to cast criminal women as Otherand the underlying message is clear: they are not like the rest of us" (1996: 19).

The portrayal of the victim-defendant in a criminal trial is hotly contested ground. In 1974, feminists rallied around Joan Little, a 20-year-old Black woman charged with killing Clarence Alligood, a 62-yearold white correctional officer at the Beaufort County, North Carolina jail. Alligood was found dead on the bunk in Little's cell with semen on his thigh. He had been stabbed 11 times. Little claimed that Alligood came to her cell carrying an ice pick, which he used to threaten her to perform oral sex on him. Alligood grabbed Little's neck and forced her to the ground. While Little was complying, Alligood loosened his grip on the ice pick. Little grabbed the ice pick and stabbed Alligood with it (Jacquet 2019).

Prosecutors and defense attorneys in Joan Little's trial offered competing visions of Little. While prosecutors characterized her as a "violent and scheming seductress," the defense realized that she would have to be seen as "sympathetic and respectable" to win acquittal (Jacquet 2019: 130). Little's attorney, Karen Galloway, explained her client's predicament thus:

Joan knew that nobody was going to believe her. Alligood had already told her that ... And she knew that was true. No one was going to believe her. She's in jail. She's a black woman. He's white. He's a male. He believes he can do anything he wants to a black woman. He's been taught that his whole life. (Jacquet 2019: 118)

Further, Alligood was not just any white man - he was a white law enforcement officer. Violence is gendered male; women like Little who use force deviate from gender norms and may be punished severely for having done so (although Little herself was acquitted) (Miller 2005).

\section{Unintended Consequences of Criminalization for Victims of Violence}

Criminalization has had significant unintended consequences for victims of intimate partner violence. Some anti-violence feminists, particularly women of color, foresaw this from the beginning of the reform 
movement (Comack 1996). While white women generally believed the criminal legal system would work for victims of gender-based violence, women of color focused on preventing that system from doing harm (Shepard and Pence 1999). Black feminists noted that support for criminalization strengthened a system that not only targeted those who used violence but also passed judgment on those who defended themselves from violence (Thuma 2019).

Investing in criminalization undoubtedly increased enforcement of the law. Mandatory arrest and no-drop prosecution policies in intimate partner violence cases prompted police to make arrests whenever they had probable cause to do so and prosecutors to pursue cases whenever they had sufficient evidence. Police and prosecutors often enforced those policies without looking closely at the context of individual incidents or asking whether the defendant was actually the victim of violence. When women used force or were accused of using force, they were subject to criminalization without regard to the context surrounding the isolated incident for which they were charged (Dasgupta 2002). "In the name of equal justice," criminologist Meda Chesney-Lind explained, law enforcement vowed to enforce laws against women just as they would against men, a phenomenon Chesney-Lind called "vengeful equity" (Chesney-Lind 2006: 6, 18).

Arrest rates of women following the inception of mandatory arrest policies tell the vengeful equity story. After adopting mandatory arrest laws, several jurisdictions in the US logged significant increases in the numbers of women arrested, both in dual arrests (when both parties are arrested) and in arrests of women only (Dasgupta 2002; Hamberger and Potente 1994; Miller and Becker 2019). After the passage of mandatory arrest laws in California, men's arrests rose by 60 percent; women's arrests increased by 400 percent. In Kenosha, Wisconsin, arrests of women increased by 1200 percent following the enactment of mandatory arrest laws. Sixteen years after mandatory arrest laws passed in Connecticut, women comprised 30 percent of all people arrested for domestic violence (Gruber 2019).

These increases would be warranted if the research suggested that women were eluding arrest prior to the passage of mandatory arrest laws or that women had grown more violent after the inception of such laws. Indeed, some claim that women are, in fact, as violent as men (Straus 2010). However, other research has shown that women are more likely to use emotional abuse (which is not generally a criminal offense) than physical violence - and that when they do use violence, they do so in self-defense (Scarduzio et al. 2016); that women are not usually the primary perpetrators of intimate partner violence (Rajan and McCloskey 2009); and that women did not become more violent after the passage of mandatory arrest laws. Instead, gender studies professor Alesha Durfee has explained, the increase is at least in part "directly attributable to the implementation of mandatory arrest policies and not simply an increased use of violence by women in intimate relationships" (2012).

Criminalization of intimate partner violence is linked to increases in the incarceration of women in the US. Approximately 10 percent of those incarcerated in the US are women and girls, making the US "one of the top incarcerators of women in the world" (Kajstura 2019). Incarceration of women in state prisons increased by 834 percent between 1978 and 2015: twice the rate of the increase in men's incarceration (Sawyer 2018). As criminologist Meda Chensey-Lind has explained, "for most of the 20th century, we imprisoned about 5,000 to 10,000 women. At the turn of the new century, we now have more than 100,000 women doing time in U.S. prisons" (Chesney-Lind 2006: 17). By the 2000s, the rate of incarceration of women in the US equaled the total incarceration rate for Western Europe (Western 2018). Studies have suggested that the growth in women's incarceration is attributable to the treatment of women by the criminal legal system, not increases in women's criminality (Owen, Wells, and Pollock 2017). Black women comprise a substantial proportion of the increased prison population, and Black and Native women are incarcerated at disproportionate rates (Kajstura 2019). Black women are incarcerated at twice and Latinas 1.3 times the rate of white women (The Sentencing Project 2019). Incarcerated women are often low income, and almost two-thirds of incarcerated women are mothers (Owen, Wells, and Pollock 2017). 


\section{Who Are Criminalized Survivors?}

Most women in prison have one thing in common: they have experienced gender-based violence. In that sense, most incarcerated women are criminalized survivors. Studies have consistently shown that anywhere from 50 to 95 percent of incarcerated women have been raped or subjected to abuse by intimate partners. Similar rates of victimization are found among adjudicated girls. Seventy-four percent of the girls held in a facility for "delinquent" girls in Ohio had been abused by family members, and 65 percent by people unrelated to them; 52 percent had been sexually abused by non-family members, and 22 percent by family members (Dichter 2015). Incarcerated women are much more likely to experience violence than men - seven times more likely to have been sexually abused and four times more likely to have been physically abused (Owen, Wells, and Pollock 2017). Many women experience more than one type of victimization, often abused by multiple people (DeHart 2008). Black survivors are more likely to be criminalized (Miller and Becker 2019), as are rural women (Dewey et al. 2019). Experiencing genderbased violence is a "defining experience" for incarcerated women (Owen 1999: 90).

"Criminalization," wrote historian Robin D. G. Kelley, "is to be subjected to regulation, containment, surveillance, and punishment, but deemed unworthy of protection" (Kelley 2020). Criminalized survivors experience criminalization in all those ways. Criminalization harms victims of intimate partner violence by using laws against them that were intended to benefit them; by empowering police, prosecutors, and other government agents to harm them in the enforcement of those laws; by creating an expectation that victims will turn to the criminal legal system, justifying harsher penalties for those who choose not to or cannot do so; and by reinforcing stereotypes about victims and punishing them when they fail to conform to those stereotypes.

Some criminalized survivors initially come to the criminal legal system seeking assistance. For example, Tiawanda Moore called the police for help during a fight with her boyfriend. Officer Jason Wilson came into Moore's room to interview her and sexually assaulted her. Moore reported the assault and met with internal affairs officers, who attempted to discourage her from reporting. Feeling pressured to drop her complaint, Moore began recording the meeting on her phone. After police became aware that Moore was recording the meeting, they notified her that it was illegal to record a conversation without the consent of all parties and arrested her for felony eavesdropping. Moore spent the next two weeks in the Cook County Jail. More than a year later, a jury found Moore not guilty. Wilson was never disciplined or charged with a crime (The Washington Post 2014).

Others seek assistance through the civil system but find themselves criminally punished nonetheless. In 2017, Kassandra Jackson sought an order protecting her from a partner's abuse. When the order was denied, Jackson hit a sign on the wall, and Magistrate Michael Bachman ordered her to be incarcerated for five days for contempt of court due to her belligerence. In 2018, Jackson returned to Bachman's court to seek another order; when told she was too late to be heard by a judicial officer that day, she began pleading with a man in the hallway. Magistrate Bachman left his courtroom, chased Jackson down, grabbed her, and directed her to his courtroom, where he found her in contempt and sentenced her to 10 days imprisonment - again because she was belligerent (Londberg 2018). Others are punished by police, prosecutors, and judges for failing to act like victims: refusing to cooperate with police investigating an incident, declining prosecutors' requests to testify, failing to appear for court after being subpoenaed, or recanting statements (Goodmark 2019).

Criminalized survivors also come to the attention of the criminal legal system as defendants. Researchers studying women's criminality have identified a variety of pathways women take to crime. The pathways approach focuses on "how the abuse and oppression of women and girls narrows their options and may place them on a trajectory where crime may be the most logical response" (Sharp 2014: 12). In her original articulation of pathways theory, sociologist Kathleen Daly described how "harmed-and-harming" women, who were abused and neglected as children, and "battered" women, who were in or had been in relationships with violent men, arrived in felony court (Daly 1992). Subsequent studies have identified 
dysfunctional intimate relationships, violence, victimization, and relationships with men engaged in criminal behavior as pathways to crime (Comack 2018; Owen, Wells, and Pollock 2017; Sharp 2014). Criminologist Beth Richie has explained that criminalized Black survivors are often "compelled to crime." Richie argued that:

gender entrapment ... the socially constructed process whereby African American women who are vulnerable to men's violence in their intimate relationship are penalized for behaviors they engage in even when the behaviors are logical extensions of their racialized gender identities, their culturally expected gender roles, and the violence in their intimate relationship (explains) how some women who participate in illegal activities do so in response to violence, the threat of violence, or coercion by their male partners. (Richie 1996: 4)

The paradigmatic image of the criminalized survivor is the woman who uses force against her partner. While they have often been characterized as either "mad" (mentally unstable or mentally ill) or "bad," women use force against their partners for a variety of reasons. In a study of 208 women arrested and sent to intervention programs for using force, women identified various motivations for their violence, including asserting their dignity, defending themselves from violence in the moment, aggression, and fending off an anticipated attack (Larance and Miller 2016). Other studies have identified retaliation for past violence, expressing emotion, relieving tension, getting attention, asserting power, and establishing a tough identity as justifications for women's use of force (Dasgupta 2002; Larance and Rousson 2015; Melton and Belknap 2003; Owen, Wells, and Pollock 2017; Weston, Marshall, and Coker 2007). However, self-defense is the most frequently given explanation for criminalized survivors' use of force. For women who believe that the legal system will not protect them, particularly Black and indigenous women, violence may seem to be (and may, in fact, be) the only way to protect themselves (Nancarrow 2019; West 2009). Sometimes, violence has the desired effect. As one woman explained:

... he, uh, never hits me now. 'Cause, uh, I fought back. I figured, 'why let this person treat me the way he does or, when I tried and treat him nice, you now? So I started fighting back. And then he quit. Because I guess he knew, uh, I wasn't going to take no shit from him (Comack 1996: 77)

Other women find that not only does the violence continue but also that they are punished for defending themselves:

... in the last seven years, Eileen has started to fight back. I asked her what happens when she does and she replied, 'I always end up in court.' Eileen has been charged four times in the past seven years. In one incident, where her husband hit and kicked her and she then hit him in return, he got 30 days and she got 8 months. (Comack 1996: 98-99)

Women also become enmeshed in the criminal legal system when they commit crimes at the direction of, and/or due to fear of, their partners. For example, women and girls convicted of prostitution are frequently trafficked by abusive partners (Richie 1996). Generally, women are much more likely to be involved in serious crimes if they have at least one male co-offender, and often those women are coerced into crimes (Becker and McCorkel 2011; DeHart 2008). A survey of incarcerated women in Oklahoma found that over 80 percent of women whose husbands were involved in their crimes and more than 75 percent of those whose boyfriends were similarly involved had been abused by their partners (Sharp 2014). College sophomore Kemba Smith's partner used violence and threats to force Smith to become part of his drug operation. "Despite the fact that (1) she tried to leave the man several times; (2) that she feared for her life, (3) that she was $7 \frac{1}{2}$ months pregnant, and (4) that she had no prior criminal record," Smith was sentenced to 24.5 years imprisonment for conspiracy to distribute cocaine (Richie 2012: 157). The fear of what an abusive partner will do if she fails to participate in his crime is hard to overstate. As Letisha explained to Richie: 
I know it's hard for people to believe, but I really thought he would kill me if I refused to go along with his scheme ... The risk of being arrested was much less scary for me than being killed by my husband. (Richie 1996: 127-28)

In her study of Black women "compelled to crime," Richie also found women who, having been abused by partners in the past, used force to protect themselves from people other than their partners. Richie explained that "when some women were the constant victims of abuse, enduring years of denial, rationalization and failed efforts to change the abuser, they responded almost instinctively to protect themselves from other men" (Richie 1996: 113). Selma, for example, shot a man who tried to steal her jacket. While her lawyer said that her history of being abused had no bearing on the crime, Selma disagreed:

for me, it explains why I shot that man. I would have never done anything like that if I wasn't well trained by my family to take care of myself and if I hadn't learned from my husband that men will do anything to get me and I'd better to try to protect myself when a man was coming to hurt me. (Richie 1996: 114)

Victims of violence are sometimes held accountable for crimes committed by others. For example, mothers subjected to abuse are frequently charged with failing to protect their children from their partners' abuse. Sebina described how her husband abused both her and her son for four years, increasing his abuse when she tried to fight back. Her husband beat the child to death, then raped Sebina. The police saw that Sebina had been beaten badly and took statements from witnesses attesting to the husband's violence. Nonetheless, Sebina was charged with second-degree murder for failing to protect her son (Richie 1996).

Anti-violence advocates have responded to the unintended consequences of criminalization for survivors by trying to fix the problems created by the carceral system within the carceral system. For example, to decrease the number of victims arrested pursuant to mandatory arrest policies, states have enacted primary aggressor provisions. These provisions require police to identify and arrest the person primarily responsible for the violence, theoretically screening out victims who defend themselves against their partners. Social science evidence suggests that these policies may have a limited impact on officer decisionmaking (Finn and Bettis 2006). To address the difficulties in successfully bringing self-defense claims, advocates have championed legislation allowing for introduction of evidence on what was once called "battered woman syndrome" and is now more often referred to as "battering and its effects." Most recently, legislation allowing judges to consider intimate partner violence in sentencing and post-conviction proceedings has been enacted in Illinois, New York and California, again with mixed results (Law 2020). Legislative and other attempts to mitigate the harms of criminalization have not worked well, if at all, because they all vest the criminal legal system with the discretion to determine whether and when such policies should apply — the same problem that once led to under-intervention by the criminal legal system.

Elizabeth Comack asked:

once the relevant connections are drawn between women's abuse histories and their troubles with the law, then it would seem relevant to query whether their incarceration serves any benefit - to the women themselves, to their families, to their communities or to the larger society. (1996: 126)

The answer to Comack's question is no - the criminal legal system is not benefiting any of these entities and, in fact, does serious harm to all of them. Some believe that the system was designed to do that harm, that it is working in exactly the way it was meant to function: policing and punishing the behavior of "nonconforming" women, particularly women of color. Regardless of intent, as long as criminalization is our primary response to intimate partner violence, survivors will always be in danger of punishment. 


\section{Abolition Feminism}

Abolition feminism offers an alternative framework for crafting responses to intimate partner violence. The prison abolition movement in the US has grown significantly in the last several years in response to police violence against Black people, the crises of hyper-criminalization and mass incarceration, and the recognition of the inhumanity of the prison system. Calls to defund the police recognize that policing is an inherently racist, inherently violent enterprise that cannot be reformed or used in the service of victims of violence (Kaba 2020). Turning to the state to address violence ignores the violence that the state inflicts, particularly on communities of color. Prison abolitionists have long argued that incarceration in violent institutions is inhumane and unlikely to create the kind of change necessary to stop imprisoned people from using violence. Abolition requires both rejecting existing carceral responses and rebuilding: as Angela Davis has explained, "both the negative process, overturning and disestablishing, but also the reconstructive process of creating something new-not just one thing, but addressing all of the enabling conditions" (Walker 2020). Prison abolitionists seek solutions rooted in systemic and social change rather than continuing to build and refine the tools of the carceral state.

Prison abolitionism has a distinctly feminist, and particularly Black feminist, history (Olufemi 2020). Abolition feminism envisions a world where:

All people would be safer. It means investing in a new kind of community, especially within communities of color, where those who are most disadvantaged are in leadership of sustained, base-building activities for justice ... Strategies to address the harm caused by violence would be grounded in these stronger, more equitable communities. Safety would come from communities, and therefore, prisons could eventually become obsolete. (Richie para. 6 2014)

Abolition feminism repurposes the money, time, and energy now being poured into the criminal legal system to rebuild community ties, envision strategies for addressing violence that do not involve the violence of the state, and implement those projects. Rather than making the private public, as early antiviolence advocates sought to do, abolition feminism makes clear the connections between state violence and "private" violence (Wilson 2020). Abolition feminists call for solutions that alleviate the conditions that create violence (e.g., economic distress and systemic racism) and strategies like community accountability, mutual aid, and transformative and restorative justice to create safety for victims of violence and hold those who do harm accountable.

So long as the criminal legal system is the primary response to intimate partner violence in the US, survivors will continue to be criminalized. Any response that vests discretion in a carceral system comprising police, prosecutors, and judges who bring their own implicit and explicit biases, embedded in structural sexism and racism, to their judgment of survivors' actions will fail to protect some survivors, particularly those who least conform to victim stereotypes. Rather than continuing to tinker with the carceral state, anti-violence advocates should turn to abolition feminism to protect criminalized survivors of violence.

Correspondence: Leigh Goodmark, Marjorie Cook Professor of Law, University of Maryland Francis King Carey School of Law, 500 W. Baltimore Street, Baltimore, Maryland 21201, United States lgoodmark@law.umaryland.edu 


\section{References}

Becker S and McCorkel J (2011) The gender of criminal opportunity: The impact of male co-offenders on women's crime. Feminist Criminology 6(2): 79-110. https://doi.org/10.1177/1557085110396501

Bronson J and Carson E (2019) Prisoners in 2017. https://www.bjs.gov/content/pub/pdf/p17.pdf

Chesney-Lind M (2006) Patriarchy, crime, and justice: Feminist criminology in an era of backlash. Feminist Criminology 1(1): 6-26. https://doi.org/10.1177/1557085105282893

Comack E (1996) Women in trouble. Halifax: Fernwood Publishing.

Comack E (2018) Coming back to jail: Women, trauma, and criminalization. Halifax: Fernwood Publishing.

Daly K (1992) Women's pathways to felony court: Feminist theories of lawbreaking and problems of representation. Review of Law and Women's Studies 2(1): 11-52.

Dasgupta S (2002) A framework for understanding women's use of nonlethal violence in intimate heterosexual relationships. Violence Against Women 8(11): 1364-1389. https://doi.org/10.1177/107780102237408

DeHart D (2008) Pathways to prison: Impact of victimization in the lives of incarcerated women. Violence Against Women 14(12): 1362-1381. https://doi.org/10.1177/1077801208327018

Dewey S, Zare B, Connolly C, Epler R, and Bratton R (2019) Outlaw women: Prison, rural violence, and poverty in the American West. New York: New York University Press.

Dichter M (2015) Women's experiences of abuse as a risk factor for incarceration: A research update. https://www.researchgate.net/publication/281784283 Women's Experiences of Abuse as a Risk Factor for I ncarceration A Research Update

Dunn J (2002) Courting disaster: Intimate stalking, culture, and criminal justice. New Brunswick: Transaction Publishers.

Durfee A (2012) Situational ambiguity and gendered patterns of arrest for intimate partner violence. Violence Against Women 18(1): 64-84. https://doi.org/10.1177/1077801212437017

Finn M and Bettis P (2006) Punitive action or gentle persuasion: Exploring police officers' justifications for using dual arrest in domestic violence cases. Violence Against Women 12(3): 268-287. https://doi.org/10.1177/1077801206286218

Goodmark L (2012) A troubled marriage: Domestic violence and the legal system. New York: New York University Press.

Goodmark L (2013) Transgender people, intimate partner abuse, and the legal system. Harvard Journal of Civil Rights-Civil Liberties 48(1): 51-104.

Goodmark L (2018) Decriminalizing domestic violence: A balanced policy approach to intimate partner violence. Oakland: University of California Press.

Goodmark L (2019) The impact of prosecutorial misconduct, overreach, and misuse of discretion on gender violence victims. Dickinson Law Review 123(3): 627-659.

Goodmark L (2020) Reimagining VAWA: Why criminalization is a failed policy and what a non-carceral VAWA could look like. Violence Against Women 27(1): 84-101. https://doi.org/10.1177/1077801220949686

Goodmark L (2021) The anti-rape and battered women's movements of the 1970s and 80s. In Brake D, Chamallas $\mathrm{M}$, and Williams V (eds) Oxford handbook on feminism and law in the United States. New York: Oxford University Press.

Gruber A (2019) The feminist war on crime: The unexpected role of women's liberation in mass incarceration. Oakland: University of California Press.

Hamberger K and Potente T (1994) Counseling for heterosexual women arrested for domestic violence: Implications for theory and practice. Violence and Victims 9(2): 125-137. https://doi.org/10 .1891/0886$\underline{6708.9 .2 .125}$

Jacquet C (2019) The injustices of rape: How activists responded to sexual violence, 1950-1980. Chapel Hill: The University of North Carolina Press.

Jones A (1996) Women who kill. Boston: Beacon Press.

Kaba M (2020) Yes, we mean literally abolish the police. https://www.nytimes.com/2020/06/12/opinion/sunday/floyd-abolish-defund-police.html

Kajstura A (2019) Women's mass incarceration: The whole pie. https://www.prisonpolicy.org/reports/pie2019women.html

Kelley R (2020) Permanent war: How the US security state criminalizes and profits off its victims. Bookforum. https://www.bookforum.com/politics/policing-the-planet-24107

Kim M (2020) The carceral creep: Gender-based violence, race, and the expansion of the punitive state, $1973-1983$. Social Problems 67(2): 251-269. https://doi.org/10.1093/socpro/spz013 
Larance L and Miller S (2016) Violence against women 23(12): 1536-1559. https://doi.org/10.1177/1077801216662340

Larance L and Rousson A (2015) Facilitating change: A process of renewal for women who have used force in their intimate heterosexual relationships. Violence Against Women 22(7): 876-891. https://doi.org/10.1177/1077801215610890

Law V (2020) New York lawmakers fear court may render domestic violence survivor law "meaningless." https://theappeal.org/new-york-lawmakers-fear-court-may-render-domestic-violence-survivor-lawmeaningless/

Londberg M (2018) Mom thrown in jail twice while seeking civil order from same county magistrate. He resigned. https://www.cincinnati.com/story/news/crime/crime-and-courts/2018/09/15/magistrate-who-resignedsentenced-same-woman-jail-before/1307436002/

Machado C (2019) In the dream house: A memoir. Minneapolis: Graywolf Press.

Mahoney M (2019). Misunderstanding Judy Norman: Theory as cause and consequence. Connecticut Law Review 51(3): 671-767.

Melamed S (2019) A Philly woman killed the boyfriend who'd threatened to put her 'in the grave.' A jury found her not guilty. https://www.inquirer.com/news/philadelphia-letoya-ramseure-castle-doctrine-women-incarceration20191219.html

Melton H and Belknap J (2003) He hits, she hits: Assessing gender differences and similarities in officially reported intimate partner violence. Criminal Justice and Behavior 30(3): 328-348. https://doi.org/10.1177/0093854803030003004

Messing J, Ward-Lasher A, Thaller J and Bagwell-Gray M (2015) The state of intimate partner violence intervention: Progress and continuing challenges. Social Work 60(4), 305-313. https://doi.org/10.1093/sw/swv027

Miller S (2005) Victims as offenders: the paradox of women's violence in relationships. New Brunswick: Rutgers University Press.

Miller S and Becker P (2019) Are we comparing apples and oranges? Exploring trauma experienced by victims of interpersonal violence and abuse and by court-involved women who have used force in relationships. Journal of Interpersonal Violence. https://doi.org/10.1177/0886260518823289

Morgan R and Truman J (2020) Criminal victimization, 2019. https://www.bjs.gov/content/pub/pdf/cv19.pdf

Musto J (2016) Control and protect: Collaboration, carceral protection, and domestic sex trafficking in the United States. Oakland: University of California Press.

Nancarrow H (2019) Unintended consequences of domestic violence law: Gendered aspirations and racialised realities. Cham: Palgrave Macmillan.

Olufemi L (2020) "We can enact the future we want now": A Black feminist history of abolition. The Guardian, 4 August. https://www.theguardian.com/books/2020/aug/03/we-can-enact-the-future-we-want-now-a-blackfeminist-history-of-abolition

Owen B (1999) Women and imprisonment in the United States: The gendered consequences of the U.S. imprisonment binge. In Cook S and Davies S (eds) Harsh punishment: International experiences of women's imprisonment: 81-98. Boston: Northeastern University Press.

Owen B, Wells J and Pollock J (2017) In search of safety: Confronting inequality in women's imprisonment. Oakland: University of California Press.

Piquero, A, Jennings, W, Jemison, E, Kaukinen, C and Knaul F (2021) Domestic violence during COVID-19: Evidence from a systematic review and meta-analysis. https://cdn.ymaws.com/counciloncj.org/resource/resmgr/covid commission/Domestic Violence_During_COV. $\underline{\mathrm{pdf}}$

Rajan M and McCloskey K (2009) Victims of intimate partner violence: Arrest rates across recent studies. In McCloskey K and Sitaker M (eds) Backs against the wall: Battered women's resistance strategies: 24-48. London: Routledge.

Ramsey C (2011) Domestic violence and state intervention in the American West and Australia, 1860-1930. Indiana Law Journal 86(1): 185-255.

Ramsey C (2013) The exit myth: Family law, gender roles, and changing attitudes toward female victims of domestic violence. Michigan Journal of Gender and the Law 20(1): 1-32.

Ramsey C (forthcoming) Houses of pain: Domestic violence and legal intervention in the United States, 1880-1994. Cambridge: Cambridge University Press.

Richie B (1996) Compelled to crime: The gender entrapment of Black battered women. London: Routledge.

Richie B (2012) Arrested justice: Black women, violence, and America's prison nation. New York: New York University Press. 
Richie B (2014) How anti-violence activism taught me to become a prison abolitionist. https://thefeministwire.com/2014/01/how-anti-violence-activism-taught-me-to-become-a-prisonabolitionist/

Ritchie A (2017) Invisible no more: Police violence against Black women and women of color. Boston: Beacon Press.

Sacco L (2019) The Violence Against Women Act (VAWA): Historical overview, funding, and reauthorization. https://www.everycrsreport.com/files/20190423 R45410 672f9e33bc12ac7ff52d47a8e6bd974d96e92f02.pd f

Sawyer W (2018) The gender divide: Tracking down women's state prison growth. https://www.prisonpolicy.org/reports/women overtime.html

Sawyer W and Wagner P (2020) Mass incarceration: The whole pie 2020. http://www.prisonpolicy.org/reports/pie2020.html?c=pie\&gclid=Cj0KCQiAmL-ABhDFARIsAKywVaeMd8v3cvVdAEvASRuDe4ZKgGiKQZvQNxWGzcTAj kPLPGqvt4aTcaAqT5EALw wcB

Scarduzio J, Carlyle K, Harris K and Savage M (2017) "Maybe she was provoked": Exploring gender stereotypes about male and female perpetrators of intimate partner violence. Violence Against Women 23(1): 89-113. https://doi.org/10.1177/1077801216636240

Schechter S (1982) Women and male violence: The visions and struggles of the battered women's movement. Boston: South End Press.

Sharp S (2014) Mean women, mean laws: Oklahoma's women prisoners. New Brunswick: Rutgers University Press.

Shepard M and Pence E (1999) An introduction: Developing a coordinated community response. In Shepard M and Pence E (eds) Coordinating community responses to domestic violence: Lessons from Duluth and beyond: 3-24. Thousand Oaks: Sage Publications.

Sherman L and Berk R (1984) The Minneapolis domestic violence experiment. Police Foundation Reports: 1-13. https://www.policefoundation.org/wp-content/uploads/2015/07/Sherman-et-al.-1984-The-MinneapolisDomestic-Violence-Experiment.pdf

Straus M (2010) Thirty years of denying the evidence on gender symmetry in partner violence: Implications for prevention and treatment. Partner Abuse 1(3): 332-362. https://doi.org/10.1891/1946-6560.1.3.332

The Sentencing Project (2019) Incarcerated women and girls. https://www.sentencingproject.org/publications/incarcerated-women-and-girls/

The Washington Post (2014) Moore v. City of Chicago. https://www.washingtonpost.com/news/volokhconspiracy/wp-content/uploads/sites/14/2014/05/MoorevCityofChicago.pdf

Thuma E (2019) All our trials: prisons policing, and the feminist fight to end violence. Urbana: University of Illinois Press.

Truman J and Morgan R (2014) Nonfatal domestic violence, 2003-2012. https://www.bjs.gov/content/pub/pdf/ndv0312.pdf

United Press International (1987) Battered wife gets six years for killing husband. https://www.upi.com/Archives/1987/03/06/Battered-wife-gets-six-years-for-killinghusband/1230542005200/

Walker H (2020) Angela Davis calls for "Abolition feminism now". https://theslot.jezebel.com/angela-davis-calls-forabolition-feminism-now-1844032657

West C (2009) "Sorry, we have to take you in": Black battered women arrested for intimate partner violence. In McCloskey K and Sitaker M (eds) Backs against the wall: Battered women's resistance strategies: 87-112. London: Routledge.

Western B (2018) Homeward: Life in the year after prison. New York: Russell Sage Foundation.

Weston R, Marshall L, and Coker A (2007) Women's motives for violent and nonviolent behaviors in conflicts. Journal of Interpersonal Violence 22(8): 1043-1065. https://doi.org/10.1177/0886260507303191

Wilson A (2020) Why feminists should support the struggle for prison and police abolition. https://www.opendemocracy.net/en/opendemocracyuk/why-feminists-should-support-struggle-prison-andpolice-abolition/

\section{Cases Cited}

Thurman v. City of Torrington, Connecticut (1984) 595 F Supp 1521 (D. Conn. 1984). 